\title{
ISLAMIC BANK ASSET GROWTH: PREDICTIVE ASSESSMENT TOWARD DOMINANT VARIABLES AFFECTING
}

\author{
Dorry Dermawan a \\ Hunainah $^{\text {b }}$ \\ Bambang Dwi Susenoc \\ Basrowi $^{\mathrm{d}}$ \\ ${ }^{a, b}$ Department of Sharia Economics, Faculty of Islamic Economics and Business, State Islamic \\ University of Sultan Maulana Hasanuddin \\ ${ }^{c, d}$ Department of Management, Faculty of Economics and Business, University of Bina Bangsa \\ dorrydermawan96@gmail.com ${ }^{\text {a }}$; hunainah@uinbanten.ac.id ${ }^{\text {b }}$; bambangds mm@binabangsa.ac.id ${ }^{c}$; \\ basrowi@binabangsa.ac.id ${ }^{d}$
}

ARTICLE HISTORY

Received:

07 May 2021

Revised:

19 July 2021

Accepted:

26 October 2021

Online available:

30 November 2021

Keywords:

Asset growth, Islamic Bank, Inflation,

Deposit Ratio, Non-Performing Financing.

*Correspondence:

Name: Bambang Dwi

Saseno

E-mail: bambangds_mm

@binabangsa.ac.cid

\section{ABSTRACT}

This study departs from asset growth in Islamic banks which has decreased in the last four years even though assets have increased every year. This research is structured to be the basis for making policies to increase the growth of assets of Islamic banks. The research design used is quantitative with the help of smart PLS ver.3.3. The number of samples is 94 people from a population of 123 employees of Islamic Banks Serang and Cilegon Branch Offices with supervisory positions and above. The sample selection in this study uses probability sampling, so that all branch offices of Islamic banks in Cilegon and Serang as well as all supervisory work units have the same opportunity to be selected as samples. The results indicate that the ones that have the biggest influence in increasing the growth of Islamic bank assets are the financing to deposit ratio and non-performing financing. This can be seen from the path coefficient value resulting from this study between financing to deposit ratio on asset growth has a coefficient value of 2.818 and non-performing financing on asset growth has a coefficient value of 3.767. Thus, both financing to deposit ratio and non-performing financing influence increasing the growth of assets of Islamic banks. The results of this study emphasize to bankers to maintain the quality of financing to remain smooth and avoid nonperforming financing. 


\section{INTRODUCTION}

Since its inception, Islamic banking has been based on two modern Islamic revival movements: no revivalist and modernist. The main purpose of establishing an Islamic financial institution is to base all aspects of the economic life of the Muslim community based on the Qur'an and As-Sunnah (Adebayo, 2011). Islamic banking is a form of existing national banking that bases its operations on Islamic (law), whose main business is to provide credit and other services in payment traffic and money circulation that operates on the principles of Islam (Ajagbe \& Brimah, 2013).

The development of Islamic banking is based on Islamic economic principles. Although it has long been a discourse among the public and Muslim and non-Muslim scientists, establishing an Islamic banking institution commercially and formally has not been long established (Rivai \& Arifin, 2010). Besides applying Islamic law and exempting transactions from the interest-free mechanism, another unique position of Islamic banks compared to conventional banks is that they can carry out business activities that are multi-finance and trading. This relates to the nature of Islamic banking transactions, which are investment and sale and purchase, as well as the very variety of financings that Islamic banks can carry out, such as financing with the principle of mutanaqisah (buying and selling), ijarah (leasing) or ijarah wa iqtina (leasing), and others (Wardiah, 2013). With business activities based on Islamic principles based on the Qur'an and AsSunnah, by leaving maitsir, gharar, haram, and usury, Islamic banks are attractive to the Indonesian people, the majority of whom are Muslims (Machmud \& Rukmana, 2010).

Table 1

Financial Services Authority

\begin{tabular}{lcccc}
\hline \multicolumn{1}{c}{ Financial Services Authority } & Institution & Branch Offices & $\begin{array}{c}\text { Sub-branch } \\
\text { Offices }\end{array}$ & Cash Offices \\
\hline Islamic Commercial Bank & 14 & 478 & 1.199 & 198 \\
Islamic Business Units & 20 & 153 & 146 & 55 \\
Islamic Rural Banks (SRB) & 167 & 119 & 0 & 208 \\
\hline Total & $\mathbf{2 0 1}$ & $\mathbf{7 5 0}$ & $\mathbf{1 . 3 4 5}$ & $\mathbf{4 6 1}$ \\
\hline
\end{tabular}

Previous studies have stated that the financial performance reports of Islamic Commercial Banks during the Covid-19 pandemic decreased due to financing customers having difficulties in financing payments (Ichsan et al., 2021). As it is known that financing in business is very influential on strengthening business capital, which will have implications for the company's performance, especially on the accumulation of profits. (Suseno et al., 2021). In this case, total assets are one indicator of the development of Islamic banking, which determines the contribution of the Islamic banking industry to national banking. In addition, total assets are also an indicator of bank size, where the 
small amount of total assets has an impact on the economic level of scale that can be carried out by Islamic banks (Sari, 2020). Based on the Islamic Banking Statistics data, although the total assets of Islamic banks increase every year, the growth of Islamic banking assets has decreased. Total assets of Islamic banks banks in 2016 IDR 254.1 trillion, an increase of $119 \%$ compared to 2015 with total assets of IDR 213.4 trillion. Whereas in 2017, the growth of the assets of Islamic banks was $113 \%$, with total assets of IDR 288 trillion. And in 2018, the growth of Islamic bank assets was not greater than the previous year, which was $110 \%$ with total assets of IDR 316.6 Trillion (Panjaitan et al., 2018).

The development of Islamic banking does not necessarily make Islamic banking stronger and stronger and able to lead the market share of the national banking industry. Especially in the era of digitalization, it requires the efforts of stakeholders of Islamic financial institutions to build a digital technology-based strategic planning model (Basrowi \& Utami, 2020; Utami, 2019; Utami \& Guzman, 2020) and also a resource innovation model (Suseno et al., 2021). It is also essential to pay attention to the digital behavior of the Muslim community (Abidin et al., 2020). For Islamic banking to increase its market share, it needs to be supported by significant growth in assets, financial literacy, and financial technology so that the benefits of Islamic banking can be obtained more broadly (Basrowi et al., 2020). Recent studies show that an increase in two Islamic financial indicators, namely third party funds and financing, is expected to increase the total asset growth of Islamic banks because these indicators show the performance of Islamic banking as an intermediary institution (Setiawan, 2020; Supriyatni, 2021). However, the distribution of funds in the form of financing is inseparable from the possibility of problematic financing called Non-Performing Financing (NPF) (Rahman \& Fatmawati, 2020; Sudiyatmoko, 2018).

By looking at the NPF ratio, it can be seen how much problem financing is compared to all financing provided by Islamic Banks. If the NPF ratio increases, the growth of Islamic bank assets can decrease (Buchory, 2017; Muksal, 2018). If the NPF in Islamic banks is getting bigger, then the bank must provide a larger Provision for Earning Asset Losses (PPAP) which in turn will aggravate the bank's financial position (Mutawali et al., 2019). Financing problem that occurs in Islamic banks is not only caused by the character of the customer or debtor; it can also be caused by economic conditions (conditions of economic). One of the economic conditions that can affect the increase in NPF is inflation.

In carrying out its role as an intermediary institution (intermediary) between economic units that experience excess funds (surplus units) and other units that are experiencing a lack of funds (deficit units), Islamic banks can use the Financing to Deposit Ratio (FDR) as a benchmark performance (Yusuf \& Surjaatmadja, 2018). FDR is used to 
determine the portion of third-party funds distributed for financing. The level of this ratio indicates the bank's liquidity, so the higher the level of the FDR of a bank, the bank is less liquid the bank that has a smaller ratio (Muhammad, 2005; Setiawan, 2020).

Based on the background above, the researcher considers the importance of conducting research on the effect of FDR, NPF, and inflation on the growth of Islamic bank assets, which aims to improve the performance of Islamic banks in Indonesia.

The novelty of this study lies in the disclosure of the dominant variables in the financial statements based on previous research that can affect the development of Islamic bank assets in Indonesia. Through this research, original factors can be found that can affect the development of Islamic bank assets in Indonesia, namely the quality of financing by always increasing its income reserves, which can affect the financial position and assets of Islamic banks.

\section{LITERATURE REVIEW}

\section{Islamic and Asset Bank}

Islamic banks are financial institutions that function to facilitate economic mechanisms in the real sector through business activities (investing, buying and selling, or others) stated by Islamic values, both macro and micro (Ansari et al., 2012). The macro values in question are justice, maslahah, the zakat system, free from interest, free from non-productive speculative activities such as gambling (maysir), things that are unclear and doubtful (gharar), and things that are corrupted or invalid (falsehood). Meanwhile, the micro values that Islamic banking actors must possess are noble qualities exemplified by the Prophet, namely shiddiq, amanah, tabligh, and fathanah.

The functions and roles of Islamic banks, which are listed in the opening of accounting standards issued by Accounting and Auditing Organization for Islamic Financial Institution (AAOIFI), are as follows: 1) Investment managers; Islamic banks can manage customer fund investment; 2) Investors; Islamic banks can invest the funds they own as well as customer funds entrusted to them; and 3) Providers of financial services and payment traffic; Islamic banks can carry out banking service activities as usual (Vinnicombe, 2010).

Implementation of social activities; As an inherent feature of Islamic financial entities, Islamic banks also have an obligation to issue and manage (collect, administer, and distribute) zakat and other social funds. Total assets are an indicator of the development of Islamic banking, which will determine the contribution of the Islamic banking industry to national banking, which is also an indicator of bank size, where the small number of total assets will have an impact on the small level of economies of scale owned by the bank (Wahyuni \& Azmi, 2019). The greater the assets owned by the 
company, the greater the size of the company. Company assets are in a balance sheet position that reflects wealth and results from sales in various forms. In banking companies, determining the company's size can be seen from the total assets owned (Wahyuni \& Azmi, 2019).

Commercial bank assets can be classified into four basic categories: 1) Assets in cash; 2) Investments in Islamic securities and other investments; 3) Financing provided, and 4) Investment in fixed assets (Eldomiaty et al., 2020).

Kartika et al. (2020) found that, there is an effect of FDR on profit sharing finance of Islamic Banks in Indonesia. Ansari et al. (2012) also found that FDR had a significant effect on Profitability in Islamic Banks. There is a significant effect between Loan to Deposit Ratio (LDR) and Return on Assets (ROA) against Stock Price at Islamic Commercial Bank in Indonesia (Rahayu et al., 2020). Saleem et al. (2021) found that DFR made a very large contribution to Economic Growth (EG). To increase EG, FDR must be increased as much as possible.

\section{Financing to Deposit Ratio (FDR)}

Islamic banking does not recognize credit (loan) in the distribution of the funds it collects. Therefore, the activities of channeling funds carried out by Islamic banks are more directed towards financing. Financing to Deposit Ratio (FDR) is a ratio or comparison between financing provided by Islamic banks and third-party funds collected by the bank (Amelia, 2015).

FDR is used to measure the extent to which financing funds come from thirdparty funds (DPK) (Eldomiaty et al., 2020). This ratio indicates the level of liquidity of Islamic banks, so the higher the number of Financing to Deposit Ratio (FDR) of a bank, the bank is classified as less liquid a bank that has a smaller Financing to Deposit Ratio (FDR). Liquidity risk that occurs in Islamic banks can reduce the assets of Islamic banks due to additional costs to overcome liquidity risk (Rasyidin, 2016).

\section{$H_{1}$ : Financing to deposit ratio has a significant positive effect on asset growth}

\section{Inflation}

In much literature, inflation is defined as a continuous increase in the general prices of an economy (Setiawan, 2020). The effect of changes in inflation on the NPF is that high inflation will cause a decrease in the real income of the community so that the standard of living of the community also decreases. Before inflation, a debtor is still able to pay his financing installments, but after inflation occurs, prices experience a high enough increase, while the debtor's income does not increase, the debtor's ability to pay 
installments weakens because most or even all his income already used to meet household needs as a result of rising prices (Mutamimah \& Chasanah, 2012).

In their research, Del Negro et al. (2015) found that inflation will affect the Financing to Deposit Ratio (FDR) and NPF. Likewise, Jalil and Rua (2016) explained that inflation is very influential on the high and low Financing to Deposit Ratio (FDR) and Non-Performing Financing (NPF). A similar study was also conducted by Zenou (2020) who found that inflation will make FDR and NPF rise. To reduce FDR and NPF it is necessary to keep inflation low. A somewhat different study was put forward by Kryeziu and Durguti (2019) that inflation will greatly affect capital growth in banking companies in the European Region. When inflation is high, capital growth will decrease. This applies to the opposite condition.

$\mathrm{H}_{2}$ : Inflation has a significant positive effect on financing to deposit ratio.

$\mathrm{H}_{3}$ : Inflation has a significant positive effect on non-performing financing

$\mathrm{H}_{4}$ : Inflation has a significant positive effect on asset growth

\section{Non Perfoming Financing (NPF)}

Problematic financing means financing which in its implementation has not reached or met the target desired by the bank, such as problematic principal returns or profit-sharing; financing that has the possibility of risk arising in the future for the bank; financing that is included in the special attention category, doubtful and non-performing as well as the current category which has the potential for arrears in returns (Eldomiaty et al., 2020).

Non-Performing Financing (NPF) is the ratio used to see how much problem financing is compared to all financing provided by Islamic banks. If the non-performing financing or non-performing loan (NPL) in conventional banks is getting bigger, then the bank is required to provide a larger Provision for Earning Asset Losses (PPAP) which in turn will worsen the bank's financial position (Wahyuni \& Azmi, 2019).

The amount of NPF allowed by Bank Indonesia is a maximum of $5 \%$. If it exceeds $5 \%$, it will affect the assessment of the bank's soundness, which will reduce the score obtained (Effendi et al., 2017). In addition, if the NPF increases, it will affect the probability of Islamic banks because this ratio shows the ability of bank management to manage non-performing financing provided by Islamic banks. The higher the NonPerforming Financing (NPF) ratio, the worse the quality of bank financing, which causes the amount of problem financing to increase (Fianto et al., 2019).

NPF affects assets negatively, meaning that any decrease in NPF will affect the increase in Islamic banking assets because the smaller the value of NPF or bad credit in 
Islamic banking. then the distribution of funds to customers can be returned to the bank so that the profit is produced or invested by the bank. When obtaining the profit-sharing margin, the bank increases its assets (Syifa, 2018). NPF will have a major impact on the growth of Indonesian Islamic Bank assets (Havidz \& Setiawan, 2015). NPF had a significant effect on the growth of Indonesian Islamic Bank assets (Syifa, 2018).

$H_{5}$ : Non-performing financing has a significant positive effect on asset growth

\section{RESEARCH METHODS}

The research design uses a quantitative paradigm emphasizing theory testing through measurement of research variables using statistical procedures. Quantitative research uses a deductive approach that aims to test the proposed hypothesis (Sugiyono, 2011). This research is basic research or basic research which aims to verify a theory or concept. Basic research does not directly aim at finding solutions to specific problems but to develop and expand the boundaries of science. This study will examine the relationship between variables and make predictions based on correlation (Jogiyanto, 2011).

This study examines the hypothesis that reveals the facts on the observed phenomenon, namely analyzing the variables that affect the growth of total Islamic banking assets. This research was conducted in all Islamic banks that have branch offices in Serang and Cilegon cities along with all their supervisory work units, both subbranches, office units, and cash offices.

Cilegon and Serang were chosen because both locations are industrial areas, with a majority Muslim community, so it would be better if Islamic banks could capture a wider market share in these two cities. When the research was conducted in December 2018, respondents were employees of Islamic banks at Serang and Cilegon branch offices with a minimum position of officer, and had worked for at least 1 year.

In this study, the number of samples that will be carried out is 94 people from a population of 123 employees of Islamic Banks, Serang and Cilegon Branch Offices, supervisory positions and above. The population that can be sampled is those who have worked in the bank for at least 1 year and are willing to fill out the instrument without any requirements. The sample selection in this study uses probability sampling in order to all employees of Islamic Banks at the Cilegon and Serang Branch Offices and all supervisory work units have the same opportunity to be selected as samples.

The operational definition of inflation is an increase in the general prices of an economy continuously which will cause a decrease in the real income of the community so that the standard of living of the community also decreases. The operational definition of NPF is the ratio used to see how much non-performing financing is 
compared to all financing provided by Islamic banks. The operational definition of Financing Deposit Ratio (FDR) is the comparison between the financing provided by Islamic banks and third party funds collected by the bank. The definition of operational total assets is one indicator of the development of Islamic banking that will determine the contribution of the Islamic banking industry to national banking, which is also an indicator of bank size, where a small total asset will have an impact on the level of small economic scale owned by banks.

This operational definition is the basis for the preparation of research instruments filled out by respondents. The instrument developed using a Likert scale with 5 alternative answers. The instrument was tested on 30 respondents who were not the research sample to determine the validity and reliability of the instrument. the results of the analysis show that all items of the instrument are valid and reliable.

Data was obtained by using a survey method, by distributing questionnaires. The scale used is a Likert scale with five alternative answers. The number of questions is 11 items, with details of four items of inflation variable, two items of FDR variable, three items of NPF variable, and two items of total asset variable. The data obtained in the form of interval data.

Data analysis in this study used the Partial Least Square (PLS) method ver.3.30. This study aims to explain the relationship between extracts (Financing to Deposit Ratio, Non-Performing Financing, Inflation, and Asset Growth) and understand the meaning of the four constructs. The PLS method was chosen because the researcher intends to analyze the contribution of each dimension and indicator. The choice of PLS was also due to the fact that the researcher wanted to analyze the data in more detail, exceeding the previous researchers who mostly used multiple regression analysis.

The evaluation of the model used in this study evaluated the Outer Model and Inner Model. The outer model is a measurement model to assess the validity and reliability of the model. In contrast, the Inner model is a structural model to predict the causality relationship between latent variables.

The following is a structural model designed based on the variables and indicators used in this study: 


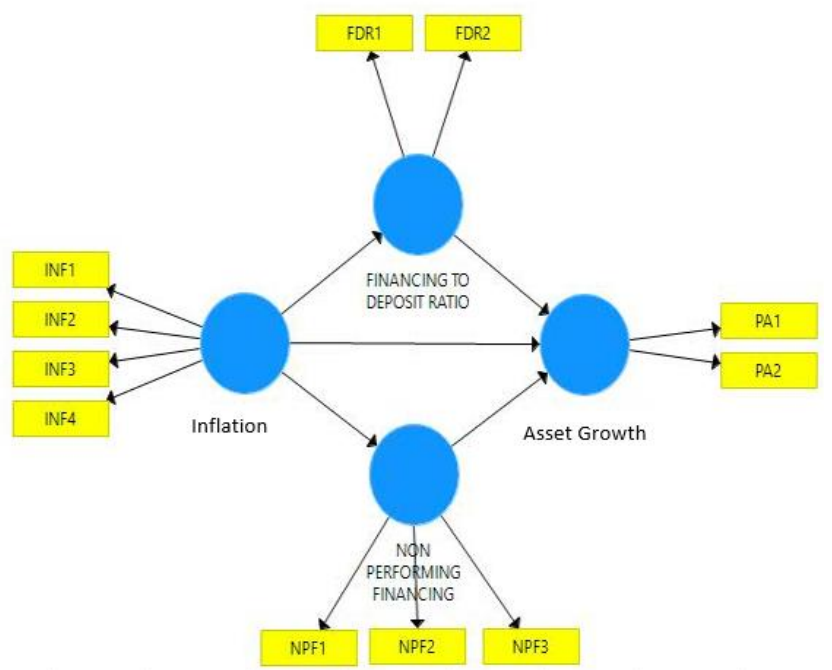

Figure 1. Initial Structural Design Model

Source: Data processed, 2020

Note: FDR1 = Total Financing; FDR2 = Total Third-Party Funds; NPF1 = Total Substandard Financing; NPF2 = Total Doubtful Financing; NPF3 = Total Loss Financing; INF1 = Consumption Price Index; INF2 = Cost of Living Index; INF3 = Producer Price Index; INF4 = Commodity Price Index; PA1 = Total Fixed Assets; PA2 = Total Current Assets

\section{RESULT AND ANALYSIS}

Based on the above model, analysis of research data through a questionnaire obtained the following results:

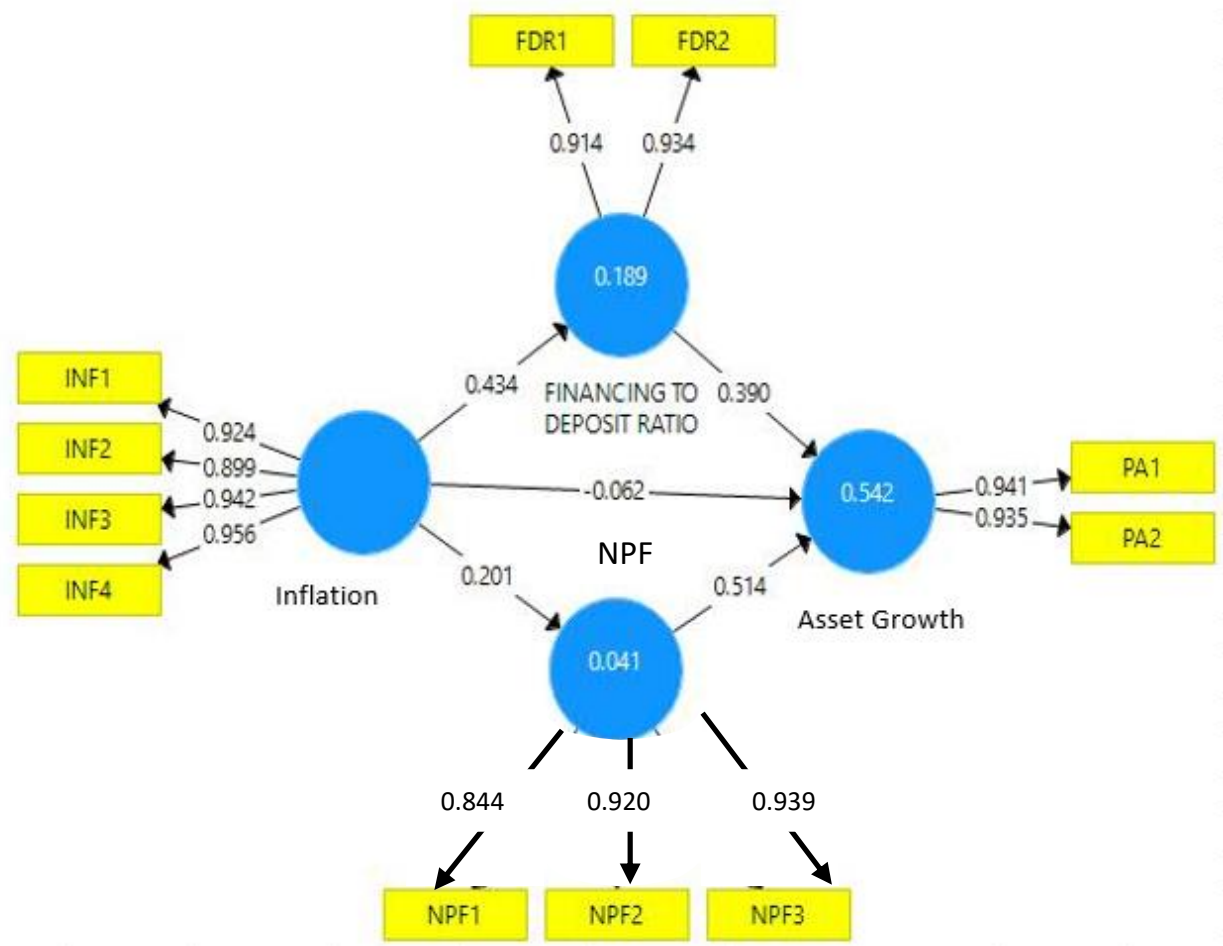

Figure 2. PLS Analysis of Initial Model Algorithm

Source: Data processed, 2020 


\section{Convergent Validity}

Convergent validity test for reflective indicators can be seen from the loading factor value for each construct indicator. By the Rule of Thumb, the loading factor value is usually used to assess the convergent validity of $>0.70$, and the average variance extracted (AVE) value must be greater than 0.5 . The following results from testing the data in this study regarding the convergent validity and average variance extracted (AVE). There are no indicators that result in a loading factor below 0.70 . The following shows the results of the calculation of primary data with the loading factor value of each indicator in a table below:

Table 2

Outer Loading value

\begin{tabular}{lcccc}
\hline & $\begin{array}{c}\text { Financing To } \\
\text { Deposit Ratio }\end{array}$ & $\begin{array}{c}\text { Non-Performing } \\
\text { Financing }\end{array}$ & Inflation & Asset Growth \\
\hline FDR1 & 0.914 & & \\
FDR2 & 0.934 & & \\
NPF1 & & 0.844 & \\
NPF2 & 0.920 & & \\
NPF3 & 0.939 & & \\
INF1 & & 0.924 & \\
INF2 & & 0.899 & \\
INF3 & & & 0.942 & 0.941 \\
INF4 & & & 0.956 & 0.935 \\
PA1 & & & & \\
PA2 & & & & \\
\hline
\end{tabular}

Source: Data Processed, 2020

After knowing the loading factor value, the next step is to know the value of the average variance extracted (AVE) with a standardized value of more than 0.5 . The following are the results of the processed data in this study. From the result, it can be seen that the value obtained from the average variance extracted (AVE) has met the Rule of Thumb criteria, which is above 0.50 .

Table 3

Average Variance Extracted (AVE) Value

\begin{tabular}{lc}
\hline & Average Variance Extracted \\
\hline Financing to Deposit Ratio & 0.854 \\
Non-Perfoming Financing & 0.814 \\
Inflation & 0.866 \\
Asset Growth & 0.880 \\
\hline
\end{tabular}

Source: Data Processed, 2020

Published by University of Airlangga.

This is an open access article under the CC BY license (https://creativecommons.org/licenses/by-nc-sa/4.0/) 


\section{Discriminant Validity}

Further discriminant validity relates to the principle that different constructs should not be highly correlated. The rule of thumb commonly used to assess discriminant validity is the value of cross loading greater than 0.70 in a study. The following is a table of the results of testing the discriminant validity in this area, which it appears that a cross-loading value is greater than 0.70 . Based on the result, the indicators meet the predetermined criteria.

Table 4

\begin{tabular}{lcccc}
\multicolumn{5}{c}{ Cross Loading Value } \\
\hline & $\begin{array}{c}\text { Financing To } \\
\text { Deposit Ratio }\end{array}$ & Inflation & $\begin{array}{c}\text { Non-Performing } \\
\text { Financing }\end{array}$ & Asset Growth \\
\hline FDR1 & 0.914 & 0.330 & 0.333 & 0.520 \\
FDR2 & 0.934 & 0.465 & 0.386 & 0.521 \\
INF1 & 0.423 & 0.924 & 0.241 & 0.233 \\
INF2 & 0.349 & 0.899 & 0.198 & 0.149 \\
INF3 & 0.403 & 0.942 & 0.154 & 0.223 \\
INF4 & 0.435 & 0.956 & 0.153 & 0.171 \\
NPF1 & 0.336 & 0.176 & 0.844 & 0.435 \\
NPF2 & 0.395 & 0.153 & 0.920 & 0.667 \\
NPF3 & 0.326 & 0.218 & 0.939 & 0.628 \\
PA1 & 0.518 & 0.212 & 0.643 & 0.941 \\
PA2 & 0.539 & 0.182 & 0.582 & 0.935 \\
\hline
\end{tabular}

Source: Data Processed, 2020

\section{Reliability}

Reliability test is intended to prove the instrument's accuracy, consistency, and accuracy in measuring constructs. In this study, to measure reliability using the measurement of Composite Reliability and Cronbach's Alpha with the Rule of Thumb value commonly used for research is greater than 0.7 . Following are the results of the calculation of the data in this study are presented below.

Table 5

Cronbach's Alphadan Composite Reliability Value

\begin{tabular}{lcc}
\hline & Cronbach's Alpha & Composite Reliability \\
\hline Financing To Deposit Ratio & 0.829 & 0.921 \\
Non Performing Financing & 0.887 & 0.929 \\
Inflation & 0.948 & 0.963 \\
Asset Growth & 0.864 & 0.936 \\
\hline
\end{tabular}

Source: Data Processed, 2020

From Table 5, the value of composite reliability for each variable is more than 0.7 , while from Cronbach's Alpha, there are variables that still get a value below 0.7 , so it can 
be concluded that the variables used do not have a good level of accuracy and consistency and the accuracy of the instruments used in this study.

Due to the outer loading test results, the model is still not fit because there are still indicators whose loading factor is below 0.7 , the value of cross-loading indicators leading to latent variables is still low, and the Cronbach's alpha value is below 0.7. Based on these results, there are several indicators of the aforementioned variables that must be removed in the first model offered.

\section{Evaluation of the Structural Model (Inner Model)}

Evaluation, The structural model in PLS is evaluated through a bootstrapping procedure. From the analysis of the bootstrapping procedure, the R-Squares value for each endogenous latent variable is the predictive strength of the structural model and the path coefficient to see the results of the significance of the influence of the variables in this study. Changes in the value of R-Squares can be used to explain the effect of exogenous/free latent variables on endogenous/bound latent variables whether they have a substantive effect, while the t-statistics value on the path coefficient is to determine the results of research on the hypothesis proposed in this study. The following are the bootstrapping test results. The second model uses an image display as below, showing that there are several values in the path coefficient less than 1.96, which indicates that the significance of the effect is still week.

Published by University of Airlangga.

This is an open access article under the CC BY license (https://creativecommons.org/licenses/by-nc-sa/4.0/) 


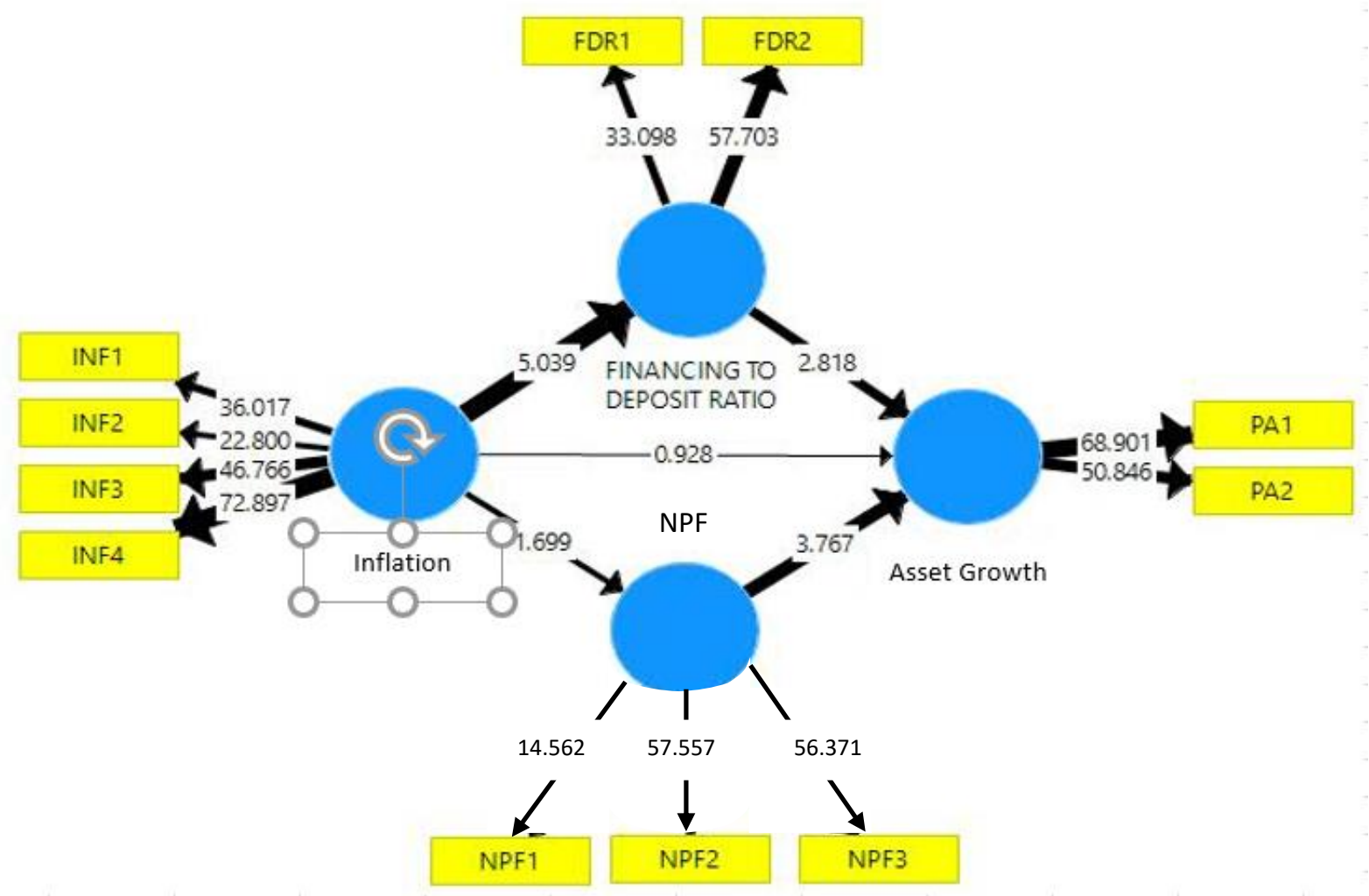

Figure 3. Bootstrapping Output Results

Source: Data Processed, 2020

\section{R-Squares Value}

The R-Squares value shows the strength of a structural model for each endogenous/dependent variable and exogenous/independent variable. The value of the R-Square for the variable:

1. The FDR is 0.189 , which means that the influence of inflation on the financing to deposit ratio is $18.9 \%$, so it can be interpreted that the financing to deposit ratio variable, which the inflation variable can explain is $18.9 \%$. In comparison, $81.1 \%$ is explained by other variables outside the one under study.

2. NPF is 0.041 , which means that the influence of inflation on non-performing financing is $4.1 \%$, so it can be interpreted that the NPF variable, which the Inflation variable can explain, is $4.1 \%$. In comparison, $95.9 \%$ is explained by other variables outside the one under study.

3. Asset growth is 0.542 , which means that the magnitude of the influence of inflation on asset growth is $54.2 \%$, so it can be interpreted that the asset growth variable which the inflation variable can explain is $54.2 \%$ while other variables outside the one understudy explain $45.8 \%$. 


\section{Dorry Dermawan, Hunainah, Bambang Dwi Suseno, Basrowi}

\section{Hypothesis Testing}

The path coefficient value shows significance in hypothesis testing with a tStatistic value above 1.96 for the hypothesis at 5 percent alpha. The following is the coefficient value of the second measurement model.

Table 6

Coefficient Value (Original Sample), Standard Error, and t-Statistics

\begin{tabular}{lcccccc}
\hline & $\begin{array}{c}\text { Original } \\
\text { Sample } \\
(\mathbf{O})\end{array}$ & $\begin{array}{c}\text { Sample } \\
\text { Mean } \\
(\mathbf{M})\end{array}$ & $\begin{array}{c}\text { Standard } \\
\text { Deviation } \\
\text { (STDEV) }\end{array}$ & $\begin{array}{c}\text { t-Statistics } \\
(\mid \mathbf{O} / \text { STDEV } \mid)\end{array}$ & P Values & Sign. Degree \\
\hline FDR $->$ Asset Growth & 0.390 & 0.405 & 0.138 & 2.818 & 0.005 & Significant \\
Inflation -> FDR & 0.434 & 0.442 & 0.086 & 5.039 & 0.000 & Significant \\
Inflation -> NPF & 0,201 & 0.209 & 0.119 & 1.699 & 0.090 & Insignificant \\
Inflation -> Financing Loss & -0.062 & -0.065 & 0.067 & 0.928 & 0.354 & Insignificant \\
NPF $>$ Asset Growth & 0.514 & 0.497 & 0.136 & 3.767 & 0.000 & Significant \\
\hline
\end{tabular}

Source: Data Processed, 2020

From Table 6 above, it can be seen the significance of the model proposed through the hypothesis in this study. Based on the results of the hypotheses that have been stated above, the researcher will discuss by comparing the results of these hypotheses with previous research journals.

\section{Effect of Financing to Deposit Ratio on Asset Growth}

The first hypothesis in the study says, FDR has a significant positive effect on Asset Grow. The coefficient value of the influence of financing to deposit ratio on asset growth is 0.390 , which means that the financing to deposit ratio has a positive effect, while the t-statistical value is 2.818 , where this value is greater than t-table 1.96 so that the hypothesis is accepted, which means that the financing to deposit ratio is significant. Has a positive effect on asset growth. The index value also evidences this. The index value of the financing to deposit ratio indicator, namely financing and third-party funds, is 0.80 , directly proportional to the value of the asset growth index with the indicator for current assets fixed assets of 0.78 . This index shows the effect of financing to deposit ratio on asset growth.

By looking at the coefficient of the influence of financing to deposit ratio on asset growth of 0.390 , which means that the financing to deposit ratio has a positive effect and the t-statistical value is 2.818 where this value is greater than $t$-table 1.96 , the result means that the hypothesis is accepted, which is the financing to deposit ratio has a significant positive effect on asset growth. This is also supported by the results of the average index for the financing to deposit ratio, which is 0.80 , which means that the 
respondent has a high-intensity response to the financing to deposit ratio variable from the respondents.

The results mentioned above have the same results with research conducted by Wahyuni and Azmi (2019), showing that non-performing financing has a positive effect on asset growth, NPF, FDR, and ROA simultaneously have a significant effect on the growth of Islamic Bank assets. The adjusted R Square value of 0.397143 shows that all independent variables NPF, FDR, and ROA can simultaneously explain the dependent variable (growth of Islamic bank assets) of $39.71 \%$. In comparison, the remaining $62.29 \%$ is explained by other variables outside the variables studied.

Hypothesis testing 1 (one) accepts that the higher the financing to deposit ratio, which is the ratio between third party funds collected and funds channeled in the form of financing, the higher the asset growth.

The main banking activities are collecting funds and channeling them back to the public or intermediary institutions from communities with excess funds to people who need funds. According to the contract scheme used, Islamic banks get profits or profits in the margin, ujrah, or profit-sharing ratio for the financing provided to the public. Funds provided in the form of financing come from funds collected from third parties; when the ratio between the funds raised and the funds channeled is small, then the profit or profit generated by the Islamic bank is small, Islamic banks cannot expand their financing. Given the limited funds to be distributed. The results showed that the financing to deposit ratio influenced asset growth. The higher the financing to deposit ratio, the higher the asset growth.

\section{Effect Of Inflation on Financing to Deposit Ratio}

The second hypothesis of this research is inflation has a significant positive effect on FDR. The value of the inflation coefficient on financing to deposit ratio is 0.434 , which means that inflation has a positive effect, while the t-statistical value is 5.039 where this value is greater than t-table 1.96 so that the hypothesis is accepted, which means that inflation has a significant positive effect on the financing to deposit ratio. The index value for each variable, inflation, and financing to deposit ratio, was equally high, namely, 0.69 and 0.80 . So that the index figures show that inflation affects the financing to deposit ratio.

By looking at the coefficient of the influence of non-performing financing on asset growth of 0.514 , which means that non-performing financing has a positive effect and the t-statistical value is 3,767 , where this value is greater than t-table 1.96 , it means that the hypothesis is accepted, which means nonperforming financing significantly to asset growth. These results are by the results of research by Sudiyatmoko (2018), which stated that non-performing financing has a significant effect on asset growth. 
Based on the test results, it can be seen that the adjusted R-square is 0.353352 or $35.3 \%$. This means that $35.3 \%$ of the dependent variable. Asset growth can be explained significantly by variations in the independent variable. The independent variables are third party funds, FDR, NPF, while the remaining $64.7 \%(100 \%-35.3 \%)$ is explained by other variables outside the regression model in this research. Based on the results of the multiple regression analysis tests, it shows that the effect of third party funds, FDR, and NPF as a whole has a significant effect on the growth of Islamic banking assets.

Hypothesis 2 (two) states that the higher the inflation rate, the higher the ratio between third-party funds collected and funds channeled in the form of financing or what is known as the financing to deposit ratio.

The public's financial condition affects the volume of third-party funds at the bank. When the consumer price index, cost of living index, producer price index, and commodity price index are high, then the funds raised in the bank will decrease because, in this position, people need cash to meet their daily needs. When people withdraw their funds from the bank, at that time, the bank's financing to deposit ratio will decrease. The results showed that inflation affects the financing to deposit ratio with a reversing effect; the higher the inflation, the lower the financing to deposit ratio.

\section{Effect of Inflation on Non-Performing Financing}

The third hypothesis of this study states, inflation has a significant positive effect on NPF. The coefficient value of the influence of inflation on non-performing financing is 0.201 , which means that inflation has a positive effect, while the t-statistical value is 0.090 , where this value is smaller than t-table 1.96 , so the hypothesis is rejected, which means that inflation is not significant for non-performing financing.

By looking at the coefficient value of the effect of inflation on asset growth of 0.062 , which means that inflation has no positive influence and the t-statistical value is 0.928 where this value is smaller than t-table 1.96 , so the hypothesis is rejected, which means that inflation has no positive effect on asset growth. It is concluded that inflation has a positive and significant effect on the financing to deposit ratio (FDR) (Ichsan et al., 2021). The financing to deposit ratio is significant for asset growth with a coefficient value of 0.390 and a t-statistic of 2.818. The results of this study are in accordance with the findings of Wahyuni and Azmi (2019) which said that inflation has a significant effect on NPF.

The rejection of the empirical test of hypothesis 3 (three) states that the higher the inflation rate, the higher the non-performing financing. The rejection of the hypothesis shows that an increase in inflation has no impact on financing quality. Customers can still fulfill their obligations in paying installments even though inflation

Published by University of Airlangga.

This is an open access article under the CC BY license (https://creativecommons.org/licenses/by-nc-sa/4.0/) 
has increased; this is because the company where the customer works has adjusted employees' take-home pay as inflation increases. In addition, the bank has also prepared a relaxation scheme for customer installments, both rescheduling and restructuring, so that the quality of financing is maintained despite rising inflation. Thus, inflation does not affect non-performing financing.

\section{Effect of Inflation on Asset Growth}

The fourth hypothesis in this study states, inflation has a significant positive effect on Asset Growth. The coefficient value of the influence of inflation on asset growth is -0.062 , which means that inflation does not have a positive effect, while the tstatistical value is 0.928 , where this value is smaller than t-table 1.96 so that the hypothesis is rejected, which means that inflation is not significant to asset growth.

The empirical test conducted has rejected hypothesis 4 (four), which states that the higher the inflation rate, the higher the asset growth. The rejection of the hypothesis shows that the increase in inflation requires the public to be available for cash. Thus the funds collected at the bank will decrease, and this will affect the decrease in the ratio of financing and funds collected. When the funds collected are reduced, the financing that can be distributed will also decrease. This decrease in financing resulted in a decrease in bank income and also asset growth.

The results of this study are in accordance with research which found that there is no effect between inflation and asset growth. Despite high inflation, asset growth remains high (Eldomiaty et al., 2020).

\section{The Effect of Non-Performing Financing on Asset Growth}

The fifth hypothesis in this study states that the NPF has a significant positive effect on asset growth. The coefficient value of the influence of non-performing financing on asset growth is 0.514 , which means that non-performing financing has a positive effect, while the t-statistical value is 3.767 where this value is greater than $t$ table 1.96 so that the hypothesis is accepted, which means that non-performing financing has a significant positive effect on asset growth. The index for the variable nonperforming financing and asset growth shows the numbers 0.76 and 0.78 so that the index figures show the effect of non-performing financing on asset growth.

The empirical test of hypothesis 5 (five) states that the higher the nonperforming financing, the higher the asset growth. After channeling financing to debtors, banks must maintain the quality of financing in a current position. Because for financing disbursed, the bank must reserve the bank's income by the quality of the financing or what is commonly known as collectability. The worse the quality of financing, the greater the collectability and the higher the bank's income that must be reserved. Thus, non- 


\section{Dorry Dermawan, Hunainah, Bambang Dwi Suseno, Basrowi}

performing financing has an effect on asset growth with a reverse effect. In a sense, the higher the non-performing financing, the lower the asset growth, and vice versa, the lower the non-performing financing, the higher the asset growth.

The research results have answered the research problem that produces variables that can affect the growth of Islamic bank assets to affect the increase in asset growth of Islamic banks. The higher the financing channeled, the higher the profit will be obtained by Islamic banks. In channeling financing, Islamic banks need third-party funds and maintain the ratio between channeled financing and funds collected at $100 \%$. The higher the third-party funds collected will make it easier for Islamic banks to expand in channeling financing. After distributing financing, Islamic banks must maintain the repayment rate always to remain $100 \%$ intact when the repayment rate is far below $100 \%$. Islamic banks must be willing to reserve their income, even for non-performing financing; Islamic banks must be willing to reserve their income equal to $100 \%$ of the outstanding value. This certainly affects the growth of Islamic bank assets. Apart from the internal process factors in Islamic banks, asset growth can also be influenced by external factors, including inflation. The high price index condition causes the public to withdraw funds from Islamic banks to meet their daily needs. Thus, the funds collected will be reduced, which is also followed by channeled financing. When financing disbursed decreases, the income of Islamic banks will also decrease. This certainly affects the growth of Islamic bank assets.

Islamic banks need to channel funds to the public because through this process, Islamic banks will get profits, both in the margin, ujrah, and profit-sharing. to distribute funds to the public in the financing, the bank must first collect public funds. How can you distribute funds if Islamic banks do not collect funds from the public? Islamic banks must pay attention to the ratio between the funds channeled and the funds raised or what is called the FDR.

\section{CONCLUSION}

Based on the research results, financing to deposit ratio and nonperforming financing are important constructs in improving the performance of Islamic banks in terms of increasing the growth of assets of Islamic banks. The findings of this study indicate that the ones that have the biggest influence in increasing the growth of Islamic bank assets are financing to deposit ratios and nonperforming financing. The policy implications of this finding can be made based on the theory that has been developed. Islamic banks will be able to get a lot of profits, when Islamic banks are able to channel financing to the maximum, the condition is that Islamic banks must have sufficient third-

party funds. The quality of funds that have been distributed to customers in the form of 
financing must be maintained. The point is not to let customers who have received the financing facility neglect their obligations in paying installments. Because if a customer is in arrears, let alone not paying installments, the non-performing financing rate will increase. This study only includes 94 respondents, and only examines the city of Cilegon and Serang, which should be able to expand its coverage area, as well as the number of research samples, so that the generalization area can be wider.

\section{ACKNOWLEDGMENT}

Thank you to all parties who have been willing to aid in terms of research funding, such as the Chancellor of UIN Sultan Maulana Hasanuddin Banten, Sharia Economics Study Program, Rector of Bina Bangsa University Serang, Banten.

\section{REFERENCES}

Abidin, A., Suryanto, T., \& Utami, P. (2020). Beyond Muamalah Principles in Digital Payment Education and its Impacts on Corruption Prevention in Indonesian Public Sectors. Journal of Social Studies Education Research, 11(3), 46-64. https://www.learntechlib.org/p/217743/

Adebayo, R. I. (2011). A study of the legal and regulatory issues of non-interest banking system in Nigeria. Journal of Islamic Banking and Finance, 28(1), 71-83.

Ajagbe, T. S., \& Brimah, A. N. (2013). Islamic Banking development and evolution: current issues and future prospects. Journal of Research in International Business and Management, 3(2), 73-79.

Amelia, E. (2015). Financial Ratio and Its Influence to Profitability in Islamic Banks. Allqtishad: Jurnal Ilmu Ekonomi Syariah, 7(2), 229-240.

Ansari, A. H., Jamal, P., \& Oseni, U. A. (2012). Sustainable development: Islamic dimension with special reference to conservation of the environment. Advances in Natural and Applied Sciences, 6(5), 607-620.

Basrowi, B., Suryanto, T., Anggraeni, E., \& Nasor, M. (2020). The Effect Of Islamic Financial Literation And Financial Technology On Islamic Financial Inclusion. $A L-$ FALAH : Journal of Islamic Economics, 5(2), 231. https://doi.org/10.29240/alfalah.v5i2.1669

Basrowi, B., \& Utami, P. (2020). Building Strategic Planning Models Based on Digital Technology in the Sharia Capital Market. Journal of Advanced Research in Law and Economics, 3(49), 747-754.

Buchory, H. A. (2017). Structure of Third Party Funds, Financing Composition and Non Performing Financing on Islamic Banking Financial Performance. Advanced Science Letters, 23(9), 8837-8842. https://doi.org/10.1166/asl.2017.9980

Del Negro, M., Giannoni, M. P., \& Schorfheide, F. (2015). Inflation in the Great Recession and New Keynesian Models. American Economic Journal: Macroeconomics, 7(1). https://doi.org/10.1257/mac.20140097

Effendi, J., Thiarany, U., \& Nursyamsiah, T. (2017). Factors Influencing Non-Performing Financing (NPF) at Sharia Banking. Walisongo: Jurnal Penelitian Sosial 


\section{Dorry Dermawan, Hunainah, Bambang Dwi Suseno, Basrowi}

Keagamaan, 25(1), 109-138. https://doi.org/10.21580/ws.25.1.1540

Eldomiaty, T., Saeed, Y., Hammam, R., \& AboulSoud, S. (2020). The associations between stock prices, inflation rates, interest rates are still persistent. Journal of Economics, Finance and Administrative Science, 25(49), 149-161.

https://doi.org/10.1108/JEFAS-10-2018-0105

Fianto, B. A., Maulida, H., \& Laila, N. (2019). Determining factors of non-performing financing in Islamic microfinance institutions. Heliyon, 5(8), e02301. https://doi.org/10.1016/j.heliyon.2019.e02301

Havidz, S. A. H., \& Setiawan, C. (2015). Bank Efficiency and Non-Performing Financing (NPF) in the Indonesian Islamic Banks. Asian Journal of Economic Modelling, 3(3), 61-79. https://doi.org/10.18488/journal.8/2015.3.3/8.3.61.79

Ichsan, R. N., Suparmin, S., Yusuf, M., Ismal, R., \& Sitompul, S. (2021). Determinant of Sharia Bank's Financial Performance during the Covid-19 Pandemic. Budapest International Research and Critics Institute (BIRCI-Journal): Humanities and Social Sciences, 4(1), 298-309. https://doi.org/10.33258/birci.v4i1.1594

Jalil, A., \& Rua, G. (2016). Inflation Expectations in the Recovery from the Great Depression. In Board of Governors of the Federal Reserve System. https://www.federalreserve.gov/econresdata/notes/feds-notes/2016/inflationexpectations-in-the-recovery-from-the-great-depression-20160830.html

Jogiyanto, J. (2011). Konsep dan Aplikasi SEM berbasis varian dalam penelitian bisnis. UPPSTIMYPKN.

Kartika, R., Jubaedah, S., \& Astuti, A. D. (2020). The Influence of Financing to Deposit Ratio, Return on Assets and Non Performing Finance on Profit Sharing Finance of Sharia Banks in Indonesia. 123(Icamer 2019), 136-140.

https://doi.org/10.2991/aebmr.k.200305.034

Kryeziu, N., \& Durguti, E. (2019). The Impact of Fiscal Deficit on Inflation Rate - Empirical Evidence Case of Eurozone. International Journal of Management Excellence, 12(2), 1814. https://doi.org/10.17722/ijme.v12i2.532

Machmud, A., \& Rukmana, H. (2010). Bank Syariah, Teori, Kebajikan, dan Studi Empiris di Indonesia. Penerbit Erlangga.

Muksal, M. (2018). The Impact of Non-Performing Financing (NPF) to Profitability (Return On Equity) at Sharia Bank in Indonesia. European Journal of Islamic Finance, $\mathrm{O}$ (11 SE-). https://doi.org/10.13135/2421-2172/2739

Mutamimah, M., \& Chasanah, S. N. Z. (2012). Analisisi Eksternal dan Internal dalam Menentukan Non Performing Financing Bank Umum Syariah di Indonesia. Jurnal Bisnis Dan Ekonomi (JBE), 19(1), 49-64.

https://unisbank.ac.id/ojs/index.php/fe3/article/view/1692

Mutawali, M., Rodoni, A., \& bin Said, M. (2019). Prevention Effectiveness of NonPerforming Financing in the Indonesian Islamic Bank. ETIKONOMI, 18(2), 259274.

Panjaitan, H., Tarmizi, Daulay, M., \& Ginting, R. (2018). Effect of awareness against taxpayers tax compliance, small and medium enterprises in medan. International 
Journal of Civil Engineering and Technology, 9(9), 465-475.

Rahayu, S., Kurnia Ningsih, H. T., \& Zukhairani, I. (2020). The Effect of Loan to Deposit Ratio (LDR), Capital Adequacy Ratio (CAR) and Return on Asset (ROA) against Stock Price at Sharia Commercial Bank in Indonesia. Icmr 2018, 681-685. https://doi.org/10.5220/0008892406810685

Rahman, T., \& Fatmawati, K. (2020). The influence of financial ratios on non performing financing of the sharia rural banks of Special Region of Yogyakarta (BPRS DIY) period 2015 - 2018. Asian Journal of Islamic Management (AJIM), 2(1), 25-35. https://doi.org/10.20885/ajim.vol2.iss1.art3

Rasyidin, D. (2016). Financing to Deposit Ratio (FDR) sebagai Salah Satu Penilaian Kesehatan Bank Umum Syariah (Syudi Kasus pada Bank BJB Syariah Cabang Serang). ISLAMICONOMIC: Jurnal Ekonomi Islam, 7(1). https://doi.org/10.32678/ijei.v7i1.34

Rivai, V., \& Arifin, A. (2010). Islamic Banking: Sebuah Teori, Konsep, dan Aplikasi. Bumi Aksara.

Saleem, A., Sági, J., \& Setiawan, B. (2021). Islamic Financial Depth, Financial Intermediation, and Sustainable Economic Growth: ARDL Approach. In Economies (Vol. 9, Issue 2). https://doi.org/10.3390/economies9020049

Sari, M. K. (2020). DETERMINANT OF TOTAL ASSETS OF SHARIA BANKS IN INDONESIA (An Error Correction Model Approach). Amwaluna: Jurnal Ekonomi Dan Keuangan Syariah, 4(2), 300-310.

Setiawan, S. A. (2020). Does Macroeconomic Condition Matter for Stock Market ? Evidence of Indonesia Stock Market Performance for 21 Years. The Indonesian Journal of Development Planning, IV(1), 27-39.

Sudiyatmoko, A. (2018). The Effect Of Intellectual Capital On Non Performing Financing And It's Implication Toward Financial Performance Of Sharia Common Banks. Scientific Journal Of Reflection: Economic, Accounting, Management and Business, 1(3), 241-250.

Sugiyono, S. (2011). Metode Penelitian Kualitatif, Kuantitatif, dan kombinasi. Alfabeta.

Supriyatni, R. (2021). The Urgency of Handling Non-Performing Financing in Sharia Banks in the Development of Indonesian Sharia Economics Urgensi Penanganan Pembiayaan Bermasalah pada Bank Syariah dalam Pengembangan Ekonomi Syariah di Indonesia A . Introduction Islamic Sharia h. 35, 26-46.

Suseno, B. D., Yusuf, F. A., \& Kurnia, D. (2021). Development of patronage ambidexterity and the performance of joint venture shopping centers in indonesia. Quality Access to Success, 22(181), 30-34.

Syifa, A. (2018). the Impact of Non Performing Finance (Npf), Capital Adequacy Ratio (Car), and Financing Deposit Ratio (Fdr) To Return on Asset (Roa) With Depositor Funds As a Moderating Variable in Islamic Banks. Jurnal Akuntansi Berkelanjutan Indonesia, 1(2), 168. https://doi.org/10.32493/jabi.v1i2.y2018.p168-179

Utami, P. (2019). Digital Banking Reflection and Zakat Accoutability Sharia Banking in Indonesia. Eastern Journal of Economics and Finance, 4(1), 31-40. https://doi.org/10.20448/809.4.1.31.40

Utami, P., \& Guzman, M. J. J. De. (2020). Innovation of Technology-Based Strategies 
Based on Environmental Examination Organizations in Islamic Banking and Finance. Asian Journal of Multidisciplinary Studies, 3(1), 117-126.

https://asianjournal.org/online/index.php/ajms/article/view/264

Vinnicombe, T. (2010). AAOIFI reporting standards: Measuring compliance. Advances in Accounting, 26(1), 55-65.

https://doi.org/https://doi.org/10.1016/j.adiac.2010.02.009

Wahyuni, M., \& Azmi, F. (2019). The effect of non performing financing volume with inflation as moderating variables on sharia commercial banks. Journal of Islamic Accounting and Finance Research, 1(1), 79-96. https://doi.org/10.21580/jiafr.2019.1.1.3776

Wardiah, M. L. (2013). Dasar-Dasar Perbankan. Pustaka Setia.

Yusuf, M., \& Surjaatmadja, S. (2018). Analysis of Financial Performance on Profitability with Non Performace Financing As Variable Moderation. International Journal of Economics and Financial Issues, 8(4), 126-132.

https://www.proquest.com/scholarly-journals/analysis-financial-performanceon-profitability/docview/2064113573/se-2

Zenou, T. (2020). American Messiahs: The Narrative Strategies of FDR and Reagan, 1933 and 1981. European Journal of American Studies, 15(2).

https://doi.org/10.4000/ejas.15963 